\title{
Rheology of Colloidal Disperse Systems
}

\author{
Takayoshi MATSUMOTO \\ Division of Forest and Biomaterials Science, Graduate School of Agriculture, Kyoto University, Kyoto 606-8502, Japan \\ Rheological properties of various colloidal disperse systems were studied in the wide view of linear and non-linear \\ viscoelasticity. The colloidal disperse systems show a unique relaxation mechanism in relatively long-time scale region, \\ which is due to heterogeneity of the system. The disperse systems of fibrous particles show extremely high viscosity and \\ large elastic modulus in comparison with that of the spherical particles.
}

Key Words: Rheology / Colloid / Fibrous particle / Emulsion model / Pulp fiber

\section{コロイド分散系のレオロジー}

\author{
松本 孝芳
}

（原稿受理：2003年11月25日）

\section{1. はじめに}

筆者がコロイド分散系の構造とレオロジー特性について 研究を始めた頃は, 高分子化学工業が隆盛を極めていた頃で あり，多くの合成高分子が開発され生産されていた，従って 筆者の周りでは, 多くの研究者が合成高分子の構造と物性に 関する研究に従事していた. これらの高分子物質は極めて特 徵的なレオロジ一的性質を示し, 特に高分子液体のそれは非 常に明瞭に分子運動性と関連付けられ精緻な研究が進展し ていた.

一方, コロイド分散系のレオロジーについては，それが古 くから注目されていたにもかかわらず, どちらかというと粗 雑な議論しか出来ない状態であった. このような中で筆者の 目標は, コロイド分散系のレオロジー特性を, 高分子液体と 同様に，粘弾性の言葉（筆者はレオロジーの “共通語” と考 えている）で議論し理解できるようにすること, さらに分子 論（あるいは粒子論）と関連付けて議論し理解できるように することであった. 拙書「分散系のレオロジー」および「コ ロイド科学のためのレオロジー」を見ていただければ，少な くとも第一の目標は幾ばくかは達成できたのではないかと 考えている. このようにすることによって, レオロジーはそ の本来の強み, すなわち特定の物質にとらわれることなく, あるいは筆者のよき師でもあった先輩の言葉を借りれば, “物質横断的”に，それぞれの物質の特性を理解し得るとい う力を発揮できるものと確信する. 寸なわち, それぞれの物 質のレオロジ一特性を，まず “共通語” で基礎的に理解し， さらにその物質特有の言葉で理解を深めることが出来るこ

₹ 606-8502 京都市左京区北白川追分町 京都大学大学院農学研究科森林科学専攻

Tel: 075-753-6246

E-mail: matsutk@kais.kyoto-u.ac.jp
と，またこのようにすることが，レオロジーを真に理解する ことにつながることと確信する.

\section{2. 分散系の粘度}

ニュートン流体中に剛体粒子の分散した系の粘度は，分散 粒子間の流体力学的相互作用の無視できる希薄分散系につ いては, 球形粒子および非球形粒子分散系について理論的に 考察されている. 1,2) せん断流動下にある希薄分散系の相対粘 度 $\eta_{r}$ は一般に次式で与えられる.

$$
\eta_{r}=1+k(p) \phi
$$

ここで $k(p)$ は粒子の軸比 $p$ （=長さ／直径，アスペクト比とも 言う）に依存する無次元数， $\phi$ は粒子の体積分率である. 球 形粒子分散系については，Einsteinの粘度式が成り立ち， $k$ は 2.5になる. 非球形粒子分散系については, 系の粘度は粒子の 流動場での配向分布に依存し複雑であるが，ブラウン運動の 寄与も取り入れて，幾つかの式が理論的に導かれている. ${ }^{2,3}$ $k$ は軸比の関数であるから, 原理的には相対粘度を測定するこ とによって，分散粒子の形状に関する情報を得ることができ る. Fig.1には回転楕円体粒子分散系における $k(p)$ と軸比の関 係を示す. ${ }^{4)} k(p)$ は $p=1$ で2.5をとり, $p$ の増加と共に増大する. 一方， $\rho$ を分散粒子の密度とすると， $k$ は次式によって極限粘 度数 (固有粘度) $[\eta]$ と関係付けられる.

$$
k=\rho[\eta]
$$

従って $k$ は溶媒中の粒子の流体力学的体積に関連する量であ る. 式(1)は粒子間の相互作用が無視できる希薄系においての み成立つ式である。濃厚系では粒子間相互作用が無視できな 
くなり，事態は複雑になる.

Figure 2には, 種々の球形粒子および繊維状粒子分散系の相 対粘度と粒子の体積分率の関係を示す. 1)この図には幾つか の理論式による予想も示してある. P7, P8, $\mathrm{C}_{12} \mathrm{E}_{8}$, Rutgers, Thomas の曲線は，球形粒子分散系に関するデータを，また， BradyおよびEinsteinは球形粒子分散系に関する理論結果であ る。一方，E8およびCellは棒状および䋊維状粒子分散系に関 する実験結果である. 繊維状粒子分散系は球形粒子分散系と 比較して，著しく高い粘度を示寸ことが分かるであろう。こ れは先に述べた $k(p)$ の值が $p$ と共に大きくなること, および基 本的には球形粒子と繊維状粒子の排除体積の違いに起因す る. 排除体積とは簡単に言えば，ある粒子の周りに他の粒子 （同一粒子の他の部分でもあり得る）が入り込めない領域の 体積である．例えば岡体兏力ポテンシャルを仮定すると，球 形粒子の場合, 他の粒子の中心が入り込めない領域は, 球形

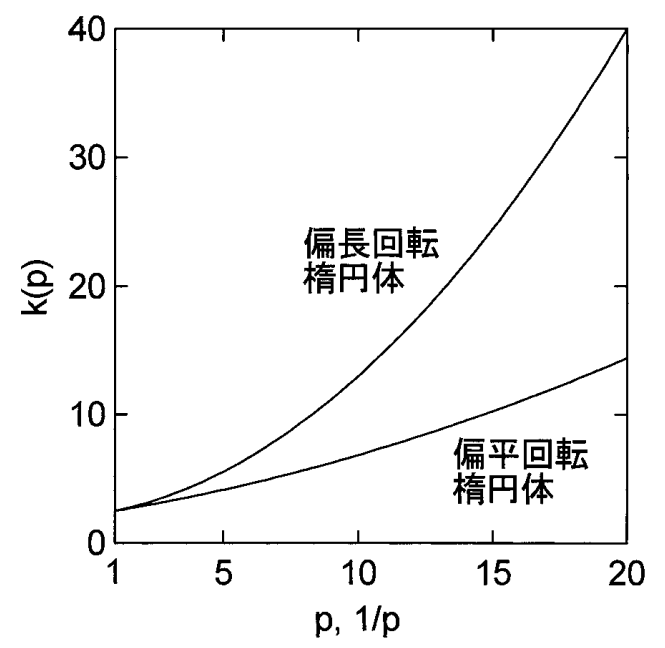

Fig.1 Factor $k$ plotted vs. aspect ratio $p$.

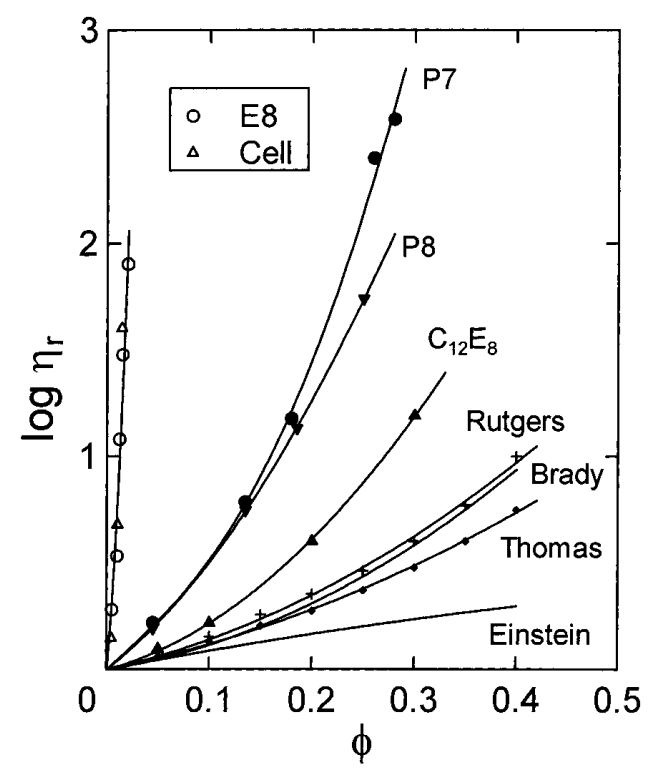

Fig.2 Relative viscosity plotted vs. volume fraction for various colloidal systems.
粒子の直径を半径とした領域で，その体積は粒子自身の体積 vの8倍である. 従って粒子 1 個あたり $4 v$ が排除体積となる. 一 方, 長さ $l$, 直径 $d$ の棒状粒子では, $(l / d) v=p v$ が排除体積とな る. 寸なわち粒子の軸比が大きければ，排除体積もそれだけ 大きくなる．排除体積が大きいということは，粒子間相互作 用を生じることなく存在し得る粒子の数が少ないことを意 味する.すなわち䋊維状粒子は球形粒子よりも遥かに低濃度 で，粒子間相互作用が無視できなくなる。これが繊維状粒子 分散系の粘度が球形粒子分散系の粘度よりも，遥かに大きく なる基本的要因である.

著者らはFig.2に示した既存の理論的結果と大きくずれる データ, しかも球形粒子および非球形粒子の分散系に適用で きる，次の実験式を提案している. 5)

$$
\ln \eta_{r}=k(p) \phi+f m^{3} \phi^{2}
$$

ここで $k(p)$ は粒子の軸比 $p$ の関数で, 球形粒子 $(p=1)$ では 2.5 , 非球形粒子 $(p \neq 1)$ では前述の非球形粒子に関する理論式で 与えられる值あるいはFig.1の值となる.fは粒子形状に僅かに 依存するとみなせる定数で，いずれの場合も約 $0.03 て ゙$ 近似さ れる． $m$ は粒子間相互作用および粒子の形状に依存する実験 的に求まる定数である. 次にこの式の適用性について述べ る. Fig.3には, ジビニルベンゼンで架橋されたポリスチレン 球形粒子のフタル酸ジエチル分散系（Fig.2におけるP7のデー タ）の流動曲線を示す．粒子濃度は5～30重量％である. 系 は粒子濃度 $15 \%$ 以下ではニュートン流動を示すが，それ以上 の濃度では僅かであるが非ニュートン流動を示す。しかしこ の場合でも低せん断速度領域および高せん断速度領域で ニュートン流動を示すことから，二つの一定粘度 $\eta_{0}$ と $\eta_{\infty}$ を得 ることができる． $\eta_{0}$ は零せん断粘度であり， $\eta_{\infty}$ は粒子が相 互の凝集力に打ち勝って個々に流動している状態の粘度と みなせる．Fig.4には， $\eta_{0}$ および $\eta_{\infty}$ と分散媒粘度の比，すな わち相対粘度 $\eta_{r}$ の自然対数と分散粒子の体積分率依存性を 示す.ここで白丸は $\eta_{0}$ に, 黒丸は $\eta_{\infty}$ に対応する相対粘度であ る. $\ln \left(\eta_{\infty} / \eta_{\mathrm{m}}\right)$ と $\phi$ の関係はほぼ直線となり，その勾配は13.8で ある.この勾配の值が式(3)における $m$ の值である.

Figure 5 には 4 種類の球形粒子分散系の $\ln \eta_{r} \sim \phi$ の関係を示

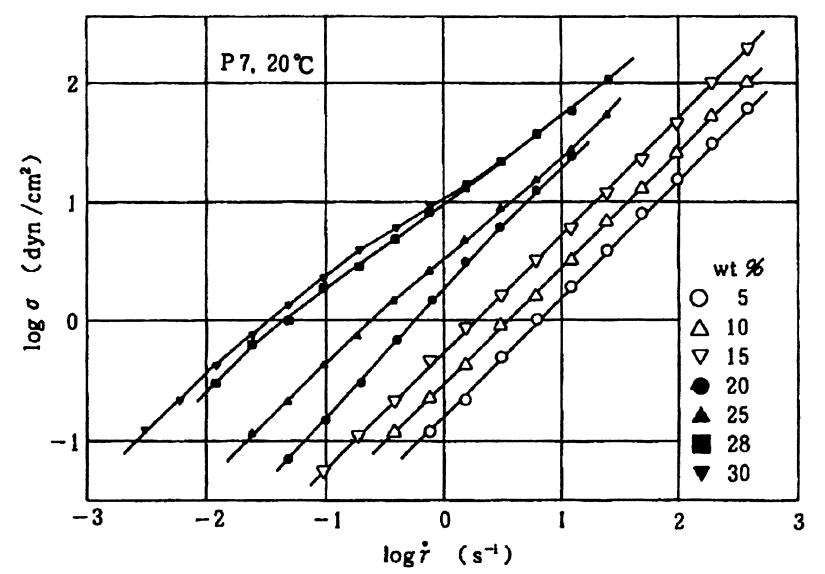

Fig.3 Flow curves for the disperse systems of P7 particle at various concentrations. 
す.この内S8およびN8は粒子表面にそれぞれ陰イオンおよび 陽イオンを持つイオン性粒子の分散系である. これらイオン 性粒子の表面電位は符号は異なるが絶対值はほぼ等しく, 従って系の粘度もほぼ等しいとみなせる. 図中の実線は式(3) で $f=0.027$ を用いた計算曲線である.

次に式(3)の棒状粒子分散系への適用性について述べる. 棒 状粒子分散系についての信頼できる実験データは少ない.

Fig.6には三上，小野木によるチタネート繊維（軸比 40～50） 分散系の流動曲線を示す。 ${ }^{6}$ 高せん断速度側の非ニュートン 性は主に分散媒の非ニュートン性に起因する。従って, 低せ ん断速度および高せん断速度側でそれぞれ一定の相対粘度 を求めることができる. Fig.7には $\ln \eta_{r} \sim \phi$ 関係を示す. $\ln \eta_{\infty}$ '

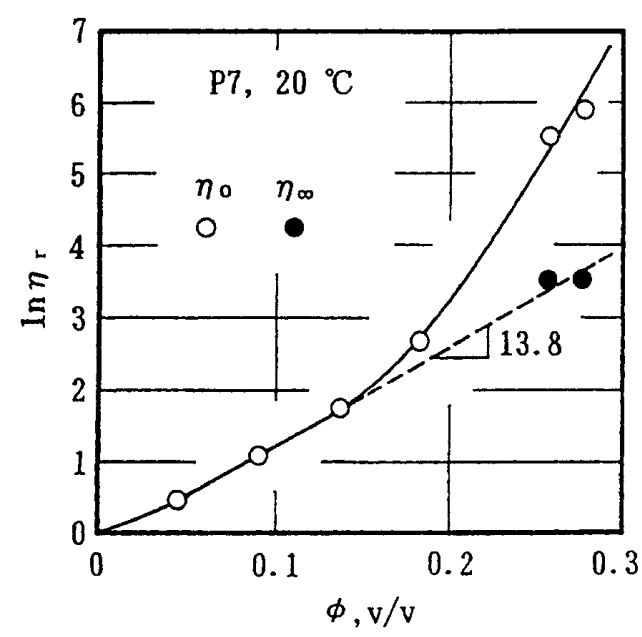

Fig.4 Relations between the relative viscosity $\eta_{r}$ and the volume fraction $\phi$ of P7 particle.

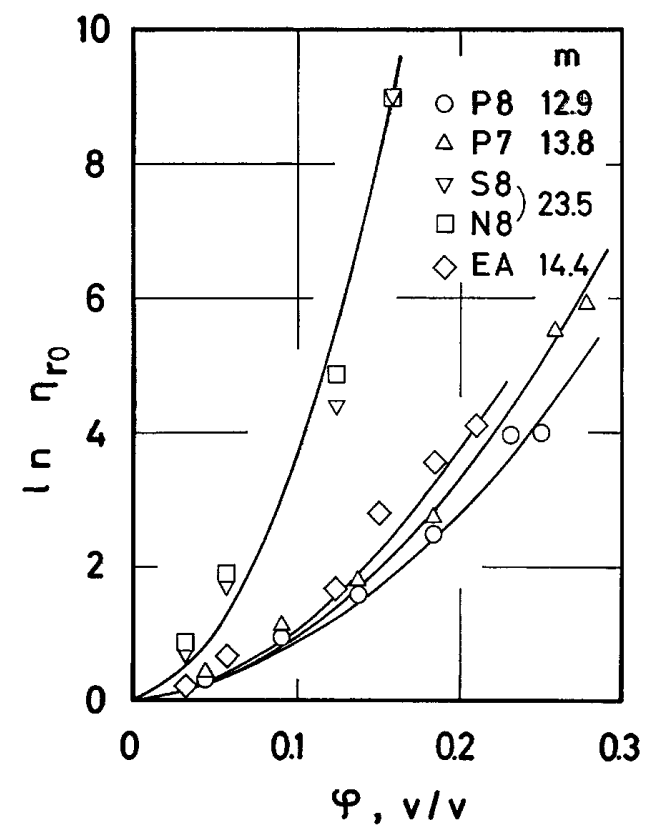

Fig.5 Relations between relative viscosity and volume fraction of the particles. Open symbols, experimental data; solid lines, calculated by Eq.(3). $\eta_{\mathrm{m}} \sim \phi$ の関係は直線になるが, その勾配は $\phi=0.007$ 付近で $m=65.2$ から35へ変化している. Simhaの理論式から求めた $k(p)$ として 215.6を用い, $f=0.033$ を用いて，式(3)からの計算結果を実線 で示す。二本の実線のうち，上側の実線は $m=65.2$ に，下の実 線は $m=35$ に対応する. 実験データとの一致は良い。この系の 特徵は棒状粒子であることによって, 粒子間相互作用が大き いことと， $\phi=0.007$ 付近で $m$ が変化（減少）することである. この原因としては，粒子一個当りの排除体積が，粒子一個当 りに割り当てられる空間の体積よりも大きくなることに よって，粒子濃度がある程度高くなると，棒状粒子はばらば らに存在するよりも, 何本か平行に配向し, 束になって存在

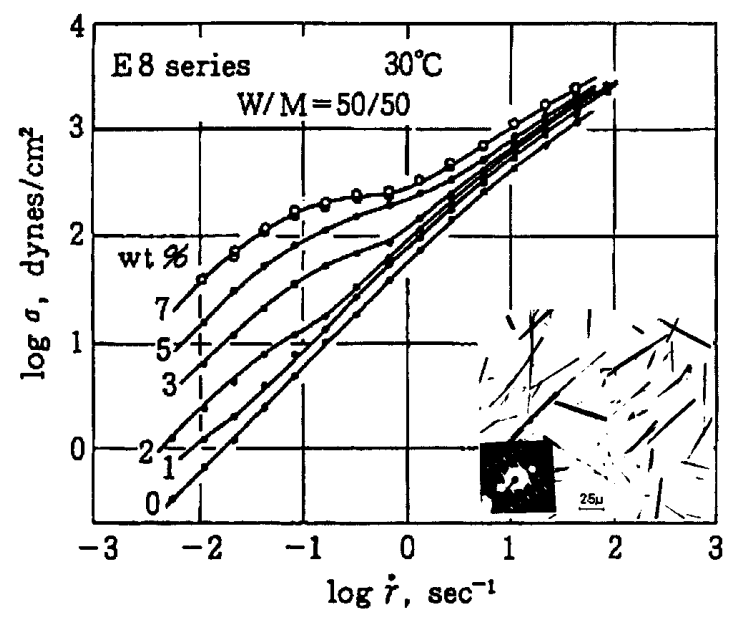

Fig.6 Flow curves of the disperse systems of titanate fibers at various concentrations and electron micrographs of the fibers.

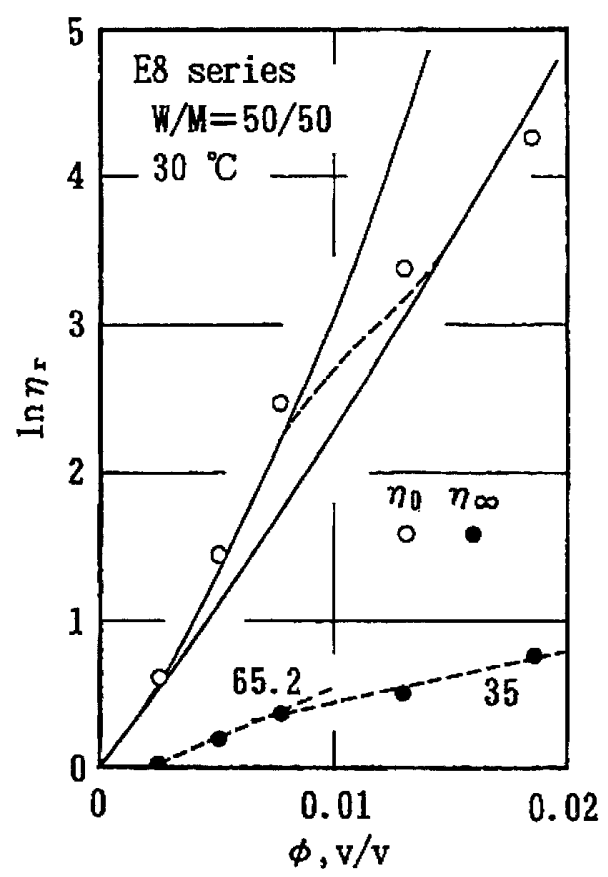

Fig.7 Relations between relative viscosity and volume fraction for the disperse system of E8 particles. Open and closed circles, experimental data; solid lines, calculated curves by Eq.(3). 


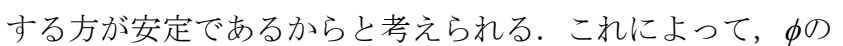
増加による粘度の増加率が低下寸るのであろう。この現象に 関するヒントとして, Onsagerの理論による isotopic-nematic転 移があげられるが，斥力のみを考慮したとき，等方相の中に ネマティック相が現れる臨界濃度 $c$ * $3.34 / p$ でちられる. ${ }^{7)}$ $p=50$ のとき $c^{*}=0.06$ となり, 上の実験值の約 10 倍である. これ とは別にFisa とUtrackiは, 棒状粒子の分散系では, $p^{-2}<\phi<p^{-1}$ の準希薄領域で粒子の運動が制限されるため, 粘度増加の割 合が低下寸ることを示している. ${ }^{8)}$

\section{3. 動的特性 一長時間緩和一}

\section{1 球形粒子分散系}

Figure 8には, ポリスチレン溶液PS10およびそれに架橋ポ リスチレン球形粒子を $10 \%$ 分散させた系の, 動的弾性率 $G^{\prime} お$ よび動的損失 $G^{\prime \prime}$ の周波数依存性を示す. ${ }^{1,9)}$ 動的測定のひずみ 振幅は $0.5 \%$ から $30 \%$ まで変化させている．ひずみ振幅 $0.5 \%$ のデータが線形性のデータである. それ以外は非線形のデー タである. 分散媒であるPS10は均質溶液であり, 低周波数で $G^{\prime} \propto \omega^{2}$ に, $G^{\prime \prime} \propto \omega$ となるので, ほぼ流動領域にあるとみなせる. 従ってFig.8は, 分散媒の流動領域より低い周波数領域, 寸な わち分散媒の最長緩和時間より長い緩和時間領域に, 不均質

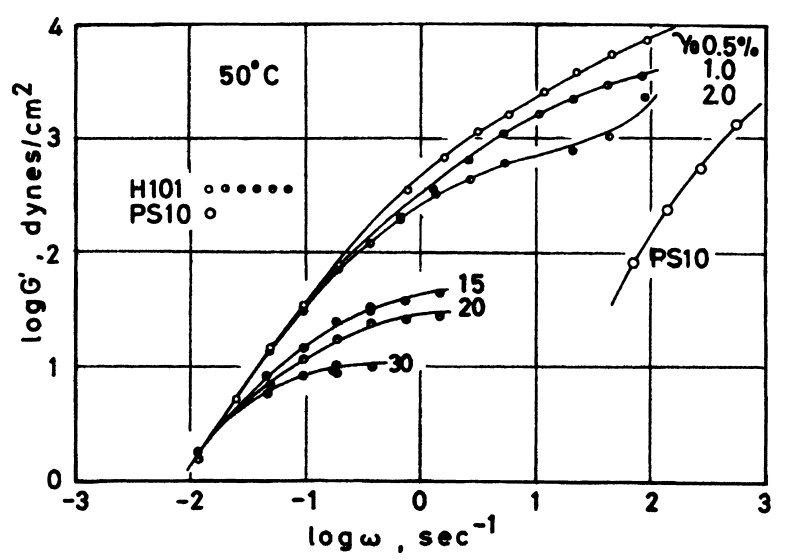

(a)

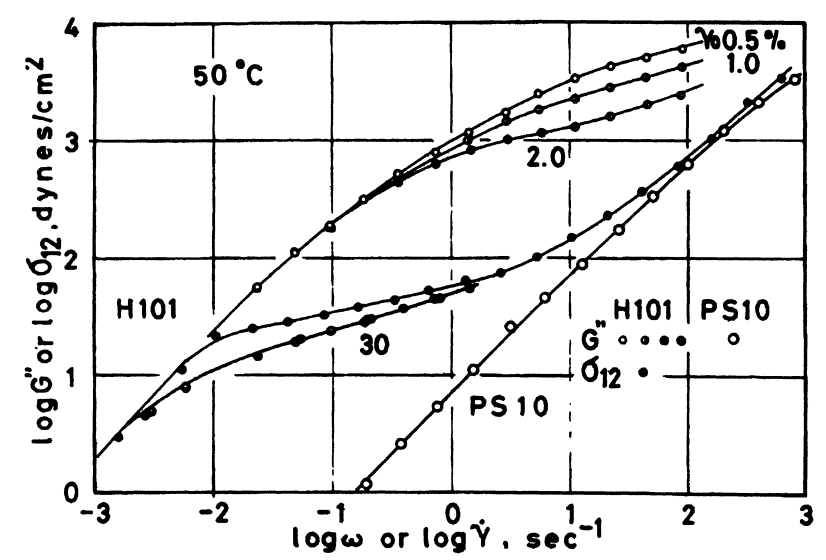

(b)

Fig.8 Logarithmic plots of storage and loss moduli vs. angular frequency for polystyrene solution PS10 and colloidal system H101. Flow curve is also plotted for H101 in (b).
系特有の緩和機構があることを示す。この緩和を長時間緩和 という.長時間緩和についての詳細は, 文献1)を参照されたい.

Figure 8(b)には, $G^{\prime \prime}$ と $\omega$ の関係とともに, せん断応力とせん 断速度の関係 $(\mathbf{O})$, ，わゆる流動曲線，も示されている. 流 動曲線は，高せん断速度側で $G^{\prime \prime}$ 曲線に沿って低下し，せん断 速度が低下寸ると, やや平坦部を示す。この平坦部が降伏応 力に相当する. 寸なわち降伏応力は長時間緩和の現れであ る.ここで注目すべき点は, さらにせん断速度が低下すると, 流動曲線は勾配1をもつ直線となること,すなわち系はニュー トン流動を示すこと, さらに，この領域で流動曲線は， $G^{\prime \prime} の$ 周波数依存性曲線と一致することである.

長時間緩和は分散粒子の凝集度に密接に関連している. Fig.9には，光の照射によって分散粒子間に架橋反応が生じ, 凝集度が増加するとともに分散系の長時間緩和がより顕著

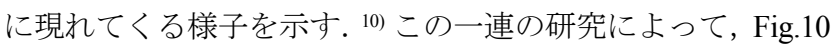
に示されるように，長時間緩和の特性緩和時間は，凝集粒子 の回転緩和時間（1/6Dr, ここでDrは回転拡散係数）と密接に 関連していることが示された.

\section{2 エマルションと界面張力}

Taylorは分散媒および分散粒子が共にニュートン液体で構 成されているエマルションの粘度について理論的に考察し

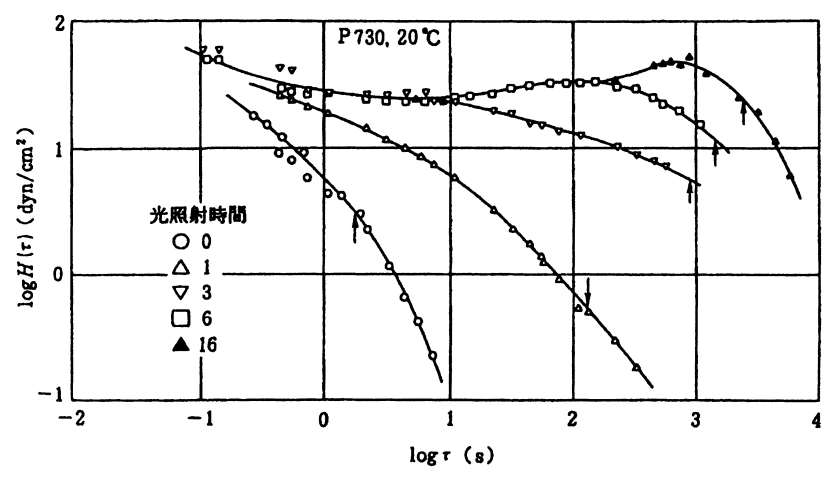

Fig.9 Relaxation spectra for suspensions of spherical particle. Arrow shows the characteristic relaxation time increasing with the degree of aggregation.

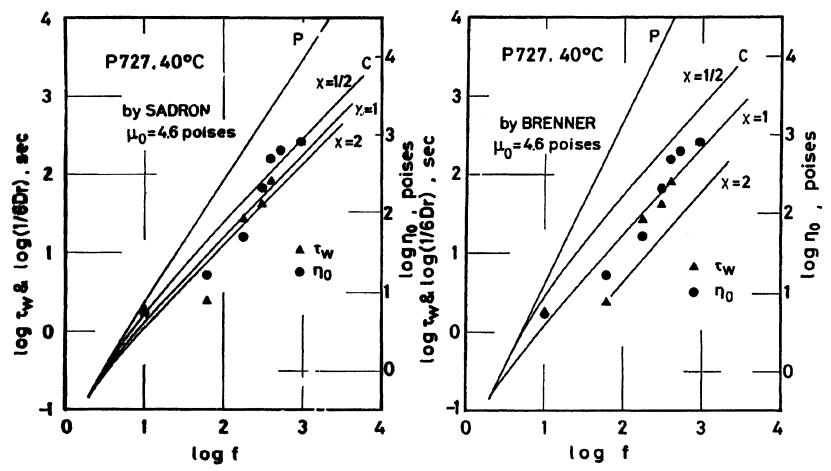

Fig.10 Logarithmic plots of $\tau_{w}, \eta_{o}$ and $1 / 6 \mathrm{D}_{\mathrm{r}}$, against degree of aggregation for the disperse systems of P7. Closed symbols, experimental data; solid lines, theoretical curves. 


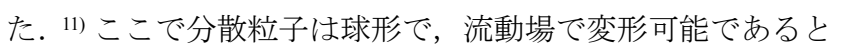
仮定されている. しかし, 実際の計算では, 粒子の変形は極 めて僅かで，無視し得る場合を扱い，次式を得ている.

$$
\eta=\eta_{m}\left[1+\left(\frac{5 K+2}{2 K+2}\right) \phi\right]
$$

ここで, $\eta_{0}$ はエマルションの零せん断粘度, $K=\eta_{i} / \eta_{m}$ で, $\eta_{i}, \eta_{m}$ はせそれぞれ分散粒子および分散媒の粘度である. $K \rightarrow \infty て ゙$, 式(4)はEinsteinの粘度式に一致する。

Schowalterらは, 分散粒子のせん断場における変形が無視し 得ない場合へ, Taylorの理論を拡張した. ${ }^{12-14)}$

この理論によれば，Fig.11に示されるように，分散粒子を 変形させようとする力はせん断応力 $\eta_{m} \dot{\gamma}$ であり, これに抗し て元の形状に復元しようとする力は界面張力に起因する応 力 $\alpha / a$ である. 従って, 粒子の平衡形状はこれらの応力の比, $\eta_{m} \dot{\gamma} a / \alpha$ (=Capillary 数, Ca) によって決る. この粒子の変形が エマルションの弾性および法線応力の原因となる.これらの エマルションモデルによれば, 複素動的弾性率は次式で与え られる. ${ }^{15)}$

$$
\begin{aligned}
& G^{*}=G{ }_{m}(\omega)\left[\frac{1+3 \phi H(\omega)}{1-2 \phi H(\omega)}\right] \\
& H(\omega)= \frac{4(\alpha / a)\left(2 G{ }^{*}{ }_{m}+5 G{ }_{i}\right)\left(G{ }_{i}-G{ }^{*}\right)}{40(\alpha / a)\left(G{ }_{i}+G{ }^{*}{ }_{m}\right)\left(2 G{ }^{*}{ }_{m}+3 G{ }_{i}\right)} \times \\
& \frac{\left(16 G{ }^{*}{ }_{m}+19 G *_{i}\right)}{\left(16 G{ }_{m}+19 G{ }_{i}\right)}
\end{aligned}
$$

ここで $G^{*}{ }_{\mathrm{m}}, G^{*}$ はそれぞれ分散媒および分散質の複素動的弾 性率である.ただし,これらは同じ周波数における值を用いる.

著者らは最近, ポリエーテルサルフォン (PES), ポリサル フォン (PSF), および両者の共通溶媒であるN-メチル-2-ピ ロリドン（NMP）の3成分系が，ある特定の濃度範囲および 温度範囲で極めて安定なエマルションを形成することを見 出した. ${ }^{16)} こ の$ 系はある条件ではFig.12に示されるような微 視的相分離状態が数ヶ月に亘って安定に存在する.

Figure13にはPES/PSF 比 3/7 系（全高分子濃度 30\%）の， $-20^{\circ} \mathrm{C} \sim 50^{\circ} \mathrm{C}$ における $G^{\prime}, G^{\prime \prime}$ の周波数依存性を示す. 測定温 度は相分離点の上下にわたっている. これらの曲線は高周波 数領域の各温度のデータに, 時間一温度換算則を用いて重ね 合わせた合成曲線である. 高周波数側の重ね合わせは良好

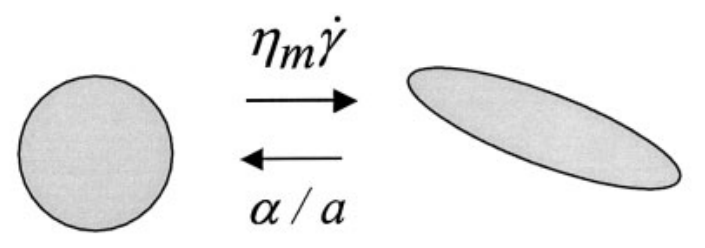

Fig.11 Deformation of the emulsion particle.
で, 移動係数の温度依存性はWLF式に従うことが確かめられ ている. 3/7系においては, 相分離温度以下ではほぼ流動領域 を示しているが，相分離温度以上では低周波数側に長時間緩

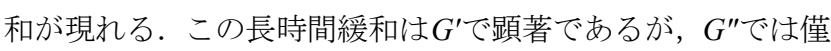
かにその影響が見られる程度である。

Figure 14には, PES/PSF(3/7)系へのエマルションモデルの 適用例を示す。これらに関する詳細は文献16)を参照された い. エマルションモデルの適用に当って用いられた $\alpha$ 值は $0.018 \mathrm{mN} / \mathrm{m}$ である. これは多くの高分子溶融物ブレンド系に おける $\alpha$ 值 (1〜数十 $\mathrm{mN} / \mathrm{m})$ と比べて数百分の一以下である. この $\alpha$ 值の異常な低さが PES/PSF/NMP系の微視的相分離状態 が非常に安定である原因と考えられる。因みに, 界面張力が $0.001 \mathrm{mN} / \mathrm{m}$ より 小さくなると, 粒子は熱エネルギーによって 自発的に分散するようになるといわれている.

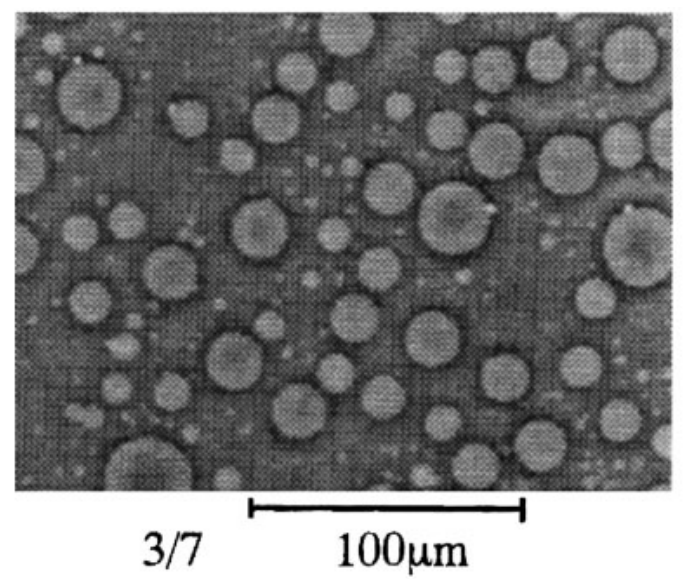

Fig.12 Photomicrograph of the PES/PSF(3/7) emulsion.

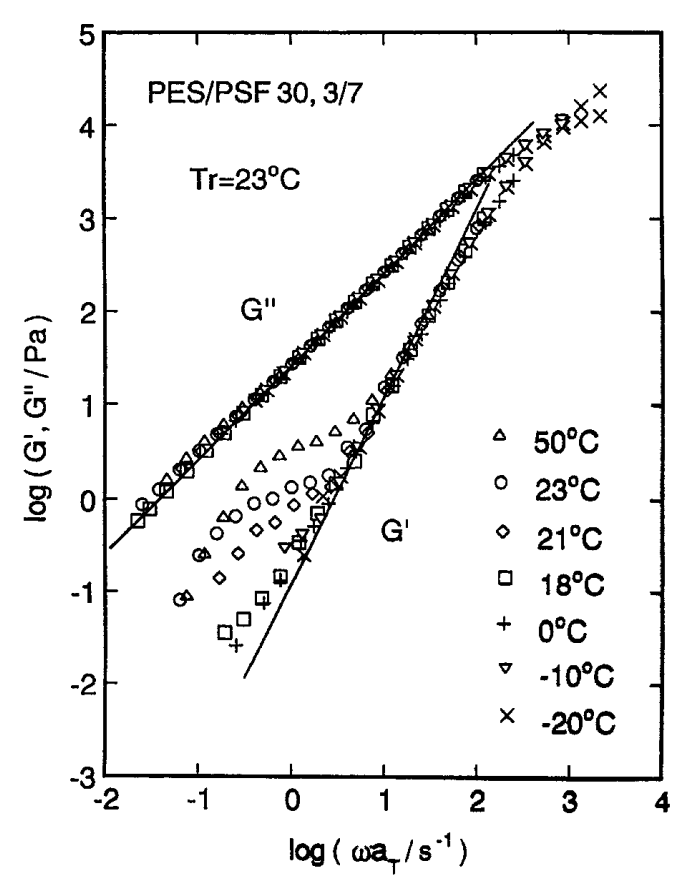

Fig.13 Frequency dependence curves of $G^{\prime}$ and $G^{\prime \prime}$ for $\operatorname{PES} / \operatorname{PSF}(3 / 7)$ system. 


\section{4. 繊維状粒子分散系}

軸比が大きければそれだけ排除体積も大きい. すなわち粒 子間相互作用を無視でき得る濃度 $c_{0}$ は, 繊維状粒子分散系で は球形粒子分散系と比較して著しく低い. Masonによればそ れは粒子 1 個の実体積とその掃引球体積の比として, 次のよ うに表される。17,18)

$$
c_{o}=\frac{3}{2 p^{2}}
$$

$c_{0}$ より低濃度では粒子は自由に回転できるが，それより高濃 度では粒子間の相互作用は無視できなくなり, 系の中に繊維 状粒子による応力を支えうる構造, 例えば網目 (様) 構造が 形成されると考えられる. その臨界濃度は式(4)によれば, 軸 比の二乗に反比例する。 ここでいう網目構造とは, 必ずしも 粒子同志が直接接触して作られる構造を意味するのではな い. 粒子のポテンシャル間の相互作用により，応力を支えう る構造もあり得るであろう。 ${ }^{19)}$

さて系の中に繊維状粒子による網目構造が形成されると, 系の零せん断粘度を測定することは極めて難しくなる．網目 構造を形成する接触点での緩和時間が著しく長くなるから と考えられている。このような状態では, 系は液体よりもむ しろ固体の特性を示すようになり, 降伏応力あるいは弾性率 に注目するほうが，系の特性を理解するために都合がよくな る. 䋊維状粒子分散系の弾性率は次式で表される.

$$
G=A c^{\beta}
$$

ここで $A$ は定数, $\beta$ はべき数で, 多くの系では $2.2 か ら 2.7$ 程 度とされている. 19-22)

我々の研究室では, 近年種々の大きさおよび軸比を持つ 繊維状粒子の分散系を用い, 式(8)の関連について検討して
いる. ${ }^{19,21)}$ Fig.15は微結晶セルロースCeolus（旭化成工業FP-3） の水分散系の動的弾性率 $G^{\prime}$ および動的損失 $G^{\prime \prime}$ の角周波数依 存性を示す. ${ }^{19)} こ の$ 粒子は長さ約 $1.7 \mu \mathrm{m}$, 太さ約 $0.077 \mu \mathrm{m}$ で, 軸比は約22である. 従って式(7)から計算される臨界濃度は約 $0.3 \%$ あるる. 事実この濃度以上では，系は明瞭な降伏応力を 示すとともに, Fig.15に見られるように, 動的粘弾性関数は 周波数軸に対しほぼ平坦になり， $G^{\prime}$ は $G^{\prime \prime}$ のほぼ 10 倍である. すなわちこの平坦部の值は，粒子の形成する網目構造に起因 する擬平衡弾性率とみなせる. Fig.16には, 種々の太さおよ び軸比をもつ繊維の分散系の動的粘弾性関数の繊維濃度依

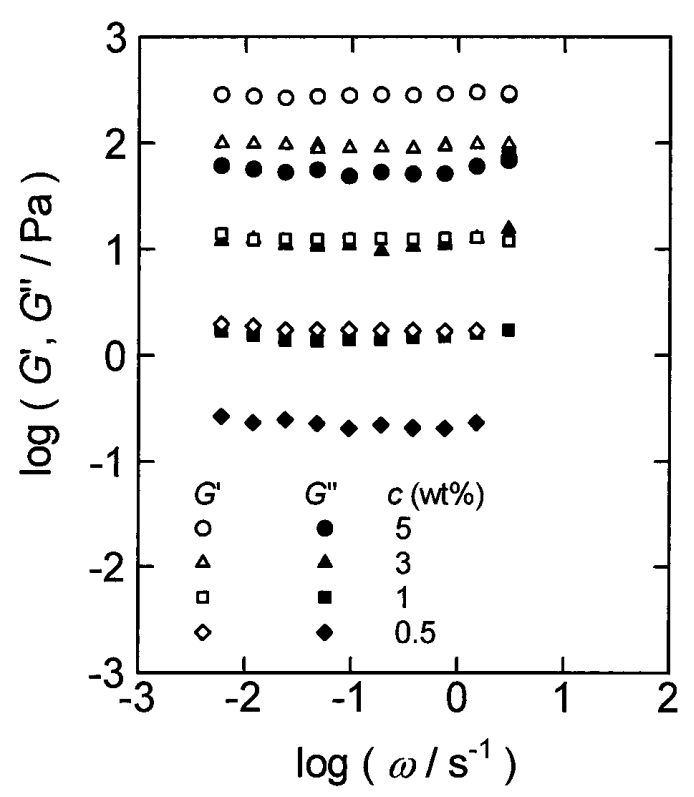

Fig.15 Logarithmic plots of $G^{\prime}$ and $G^{\prime \prime}$ vs. angular frequency for the colloidal systems of fibrous particle.

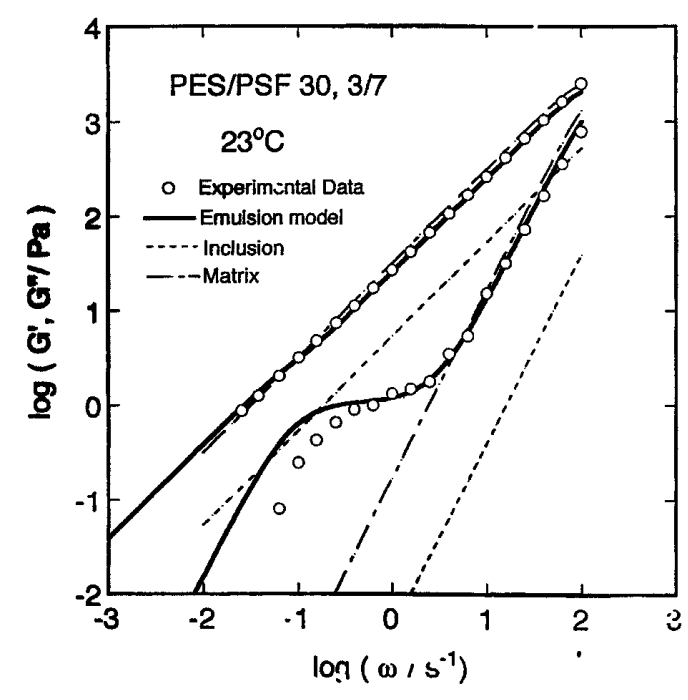

Fig.14 Comparison between the emulsion model and the experimental data for PES/PSF(3/7) system.

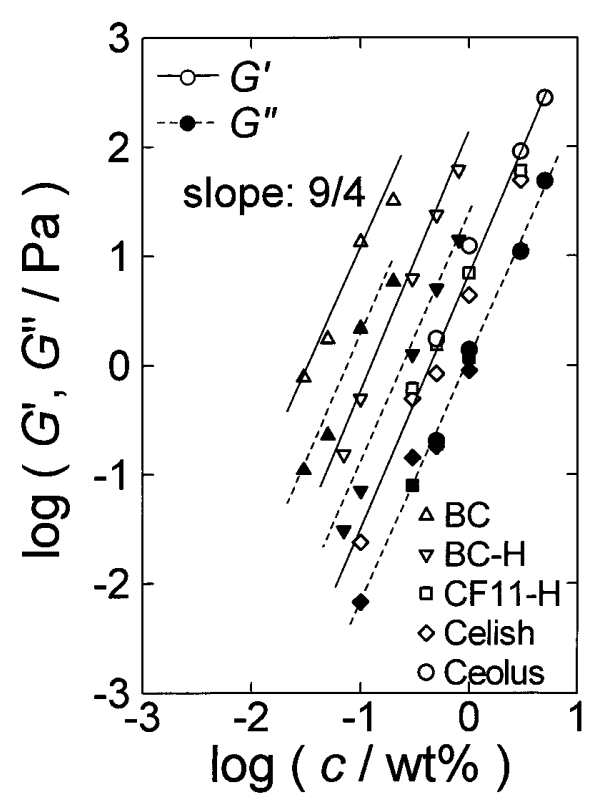

Fig.16 Logarithmic plots of $G^{\prime}$ and $G^{\prime \prime}$ vs. fiber concentration. 
存性を示す. $G^{\prime}$ は $G^{\prime \prime} よ り$ 高く, いずれの分散系でも式(8)に示 されるように, $G^{\prime}, G^{\prime \prime}$ は濃度のべき乗に比例して増加し, そ

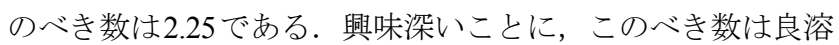
媒中の高分子ゲルおよび濃厚高分子溶液に関する值と一致 する. ${ }^{23,24,25)}$ なお，式(8)の $A$ は軸比の二乗に比例することが, 我々の実験で確認されている. ${ }^{21)}$ Fig.17は吉永ら ${ }^{26)}$ による図を もとに, 我々の実験結果を取り入れ, 擬平衡弾性率を式(8)を 用いて統一的に整理できる範囲を, 分子のレベルから木材パ ルプまで拡張した図である.

\section{5. おわりに}

この度, 日本レオロジ一学会功績賞の受賞を, 大変うれし く思います。これもひとえに小野木重治先生始め, 升田利史 郎先生および多くの先生・先輩方のご指導，ご支援によるも のと深く感謝いたします。 また，この受賞は，京都大学工学 部・工学研究科で, さらには農学研究科で, 多くの優秀なス タッフと学生諸氏とともに行った研究成果によります。これ らの皆様に深く感謝する次第です.

最後になりましたが, 本学会の益々の発展を祈念いたし ます。
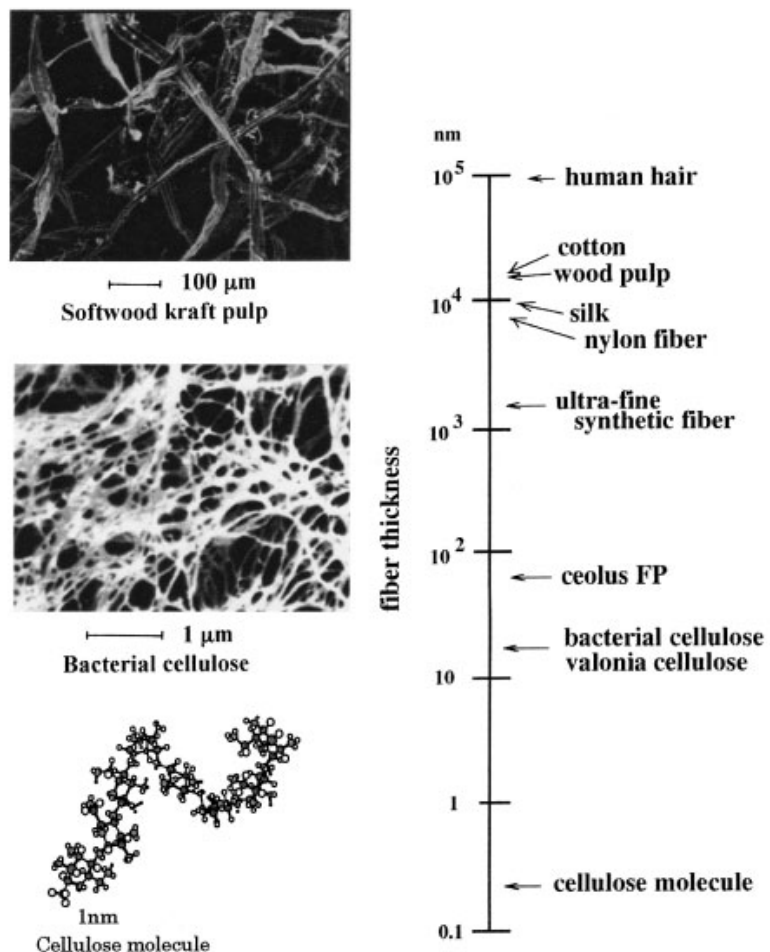

Fig.17 Schematic diagram of applicable systems of Eq.(8) from molecule to wood pulp fiber.

\section{REFERENCES}

1) Matsumoto T, "Rheology of Disperse Systems", Koubunnshi Kankokai (Kyoto), Chap.2, 1997. "Rheology for Colloid Science", Maruzen (Tokyo), Chap.6, 2003.

2) Sadron Ch, "Flow properties of Disperse systems", Hermans JJ ed., North Holland, Amsterdam, Chap.4 (1953).

3) Kuhn W, Kuhn H, Buchme Pr, Ergeb Exakt Naturw, 25, 1 (1951).

4) Barrow GM, "Physical Chemistry" 5th ed., Trans. Hujishiro K, Tokyo Kagakudojin, (Tokyo), p839, 1993.

5) Yao S, Matsumoto T, J Non-Newtonian Fluid Mech, 25, 197 (1987).

6) Mikami Y, Onogi S, Nihon Reoroji Gakkaishi, 5, 110 (1977).

7) “Kobunnshi Shuugoutai no Keiseito Seishitsu", Ed. The Soc Polym Sci, Chap.4, Kyoritsu Shuppan (Tokyo), 1993.

8) Fisa B, Utracki LA, Polym Compos, 5, 36 (1984).

9) Matsumoto T, Hitomi C, Onogi S, Trans Soc Rheol, 19, 541 (1975).

10) Matsumoto T, Yao S, Onogi S, J Rheol, 29, 177 (1985).

11) Taylor GI, Proc Roy Soc London, A138, 41 (1932).

12) Brenner H, Chem Eng Sci, 19, 519 (1964).

13) Schowalter WR, Chaffey CE, Brenner H, J Coll Inter Sci, 26, 152 (1968).

14) Scholz P, Froelich D, Muller R, J Rheol, 33, 481 (1989).

15) Parierne JF, Rheol Acta, 29, 204 (1990).

16) Matsumoto $\mathrm{T}$, Hori N, Takahashi M, Langmuir, 12, 5563 (1996).

17) Mason SG, Pulp Paper Mag Can, 51, $94-98$ (1950).

18) Kerekes RJ, Schell CJ, J Pulp \& Paper Sci, 18, j32 (1992).

19) Tatsumi D, Ishioka S, Matsumoto T, Nihon Reoroji Gakkaishi, 27, 243 (1999).

20) Kerekes RJ, Soszynski RM, Tam Doo PA, "Paper Making Raw Materials”, Mechanical Eng Pub London, 1985.

21) Tatsumi $\mathrm{D}$, Ishioka $\mathrm{S}$, Matsumoto $\mathrm{T}$, Nihon Reoroji Gakkaishi, 30, 27 (2002).

22) Damani R, Powell RL, Hagen N, Can J Chem Eng, 71, 676 (1993).

23) de Gennes P-D, "Scaling Concepts in Polymer Physics", Cornel Univ Press, Ithaca, 1979.

24) Masuda T, Ohta $Y$, Kitamura M, Minamide M, Kato K, Onogi S, Polym J, 13, 869 (1981).

25) Tada T, Matsumoto T, Masuda T, Carbohyd Polym, 39, 53-59 (1999).

26) Yoshinaga F, Tonouchi N, Watanabe K, Biosci Biotech Biochem, 61, 219-234 (1977). 